\title{
Vibrational and Thermal Properties of Crystalline Topiramate
}

\author{
Diniz M. Sena Jr., ${ }^{a}$ Paulo T. C. Freire, ${ }^{*, b}$ Josué M. Filho, ${ }^{b}$ Francisco E. A. Melo, ${ }^{b}$ \\ Fenelon M. Pontes, ${ }^{c}$ Elson Longo, ${ }^{d}$ Odair P. Ferreira ${ }^{e}$ and Oswaldo L. Alves ${ }^{e}$ \\ ${ }^{a}$ Universidade Regional do Cariri, 63105-000 Crato-CE, Brazil \\ ${ }^{b}$ Departamento de Física, Universidade Federal do Ceará, 60455-760 Fortaleza-CE, Brazil \\ 'Faculdade de Ciências, Universidade Estadual Paulista, Bauru-SP, Brazil \\ ${ }^{d}$ Instituto de Química, Universidade Estadual Paulista, PO Box 355, 14801-970 Araraquara-SP, Brazil \\ ${ }^{e}$ Laboratório de Química do Estado Sólido, Instituto de Química, Universidade Estadual de Campinas, \\ CP 6154, 13081-970 Campinas-SP, Brazil
}

\begin{abstract}
O topiramato, que é uma poderosa droga anticonvulsiva utilizada para controlar os sintomas da epilepsia, foi investigado pelas técnicas de difratometria de raios X, FT-Raman, FT-infravermelho, análise termogravimétrica, análise térmica diferencial e cálculos com teoria do funcional de densidade. A partir deste estudo foi possível identificar a maior parte das bandas observadas nos espectros Raman e infravermelho. Das análises térmicas, efetuadas da temperatura ambiente até $900{ }^{\circ} \mathrm{C}$, verificou-se que o material não apresenta nenhuma mudança de fase e que a decomposição ocorre num processo exotérmico de duas etapas.
\end{abstract}

Topiramate, a powerful anticonvulsant drug, was investigated by X-ray diffractometry, FT-Raman, FT-IR, TGA and DTA techniques as well as by DFT calculations. From this study it was possible to tentatively assign most of the normal vibrational modes of the crystal. Thermal analysis from room temperature to $900{ }^{\circ} \mathrm{C}$ shows that the material does not present any structural phase transition and that the decomposition occurs in a two-step exothermic process.

Keywords: organic crystals, vibrational spectra, X-ray diffraction, thermodynamic properties

\section{Introduction}

Epilepsy is a set of neurological disorders that range from brief cessation of responsiveness to severe muscle spasms with a loss of conciousness. In the last years some drugs have been tailored with the objective of controlling epileptic symptoms, the so called anticonvulsant drugs. Among these drugs, one of the most efficient and powerful as antiepileptic is topiramate, ${ }^{1}$ a crystalline white powder of molecular formula $\mathrm{C}_{12} \mathrm{H}_{21} \mathrm{NO}_{8} \mathrm{~S}$ and structural formula shown in Figure 1. Topiramate (2,3:4,5-bis- $O$ methylethylidene- $\beta$ - $D$-fructopyranose sulfamate) is derived from a monosaccharide by addition of a sulfamate group, and was discovered by Maryanoff et al. ${ }^{2}$ in 1987, exhibiting a remarkable anticonvulsant activity. Since the late 1990s it has been used to treat epilepsy (its trade names are

*e-mail: tarso@fisica.ufc.br

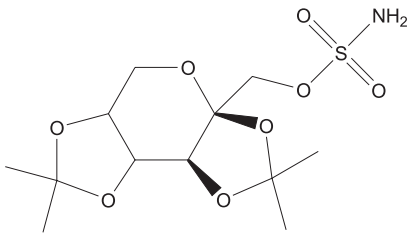

Figure 1. Structural formula of topiramate.

Topamax $®$, Topimax $®$ or Topamac $®)$ and has recently also been used to prevent migraine headaches in adults. ${ }^{3}$

In the last years, many works have reported physicalchemical characterization of drugs in order to determine several important aspects, such as the influence of processing and formulation of solid pharmaceuticals, polymorphisms, the relationship between physical structures and their properties, among others. ${ }^{4}$ Although many clinical properties of topiramate have already been investigated, very few papers address its structural and physical-chemical properties. One of these is from 
Kubicki et al., ${ }^{5}$ which presents a detailed description of its crystal structure obtained from X-ray diffraction data. The crystal belongs to the orthorhombic system, space group $\mathrm{P} 2,2,2$, with cell parameters $a=7.2497 \AA, b=11.0007 \AA$, $c=19.6291 \AA$, and $\mathrm{Z}=4$. Also, there are some works published on stability analysis of topiramate, ${ }^{6}$ especially on the development of techniques to detect sulfamate and sulfate ions resulting from topiramate decomposition. However, neither thermogravimetric analysis (TGA) nor differential thermal analysis (DTA) results were shown or discussed with regard to possible phase transitions or to further characterize thermal events. On the other hand, Fourier transform (FT)-Raman and FT-infrared (IR) spectroscopies have been used in the last years as alternative techniques to characterize drug molecules, to reveal the solid-state properties arising from polymorphism, and to identify active ingredients and excipients in a drug mixture, among others. ${ }^{?}$

The purpose of this paper is two-fold. First, to present the FT-Raman and FT-IR spectra of topiramate, providing a tentative assignment of the bands observed. Second, we shed light on the thermal behavior of topiramate crystal, in particular, reporting a two-step, exothermic decomposition process.

\section{Experimental}

Topiramate (HPLC 99.7\%) was provided by JanssenCilag Farmacêutica S.A. and used without further purification. In order to obtain the crystals, a saturated aqueous solution was prepared and left to stand at $293 \mathrm{~K}$. Within a week, small, colorless crystals (up to $3 \mathrm{~mm}$ on the longest axis), parallelepiped shaped, were collected. $\mathrm{X}$-ray powder diffraction data were collected on a Rigaku D/MAX 2400, using a $\theta$ - $2 \theta$ geometry, rotating anode source, $\mathrm{Cu}-\mathrm{K}_{\alpha}$ radiation $(1.542 \AA$ ) and scintillation detector. Typical $2 \theta$ angular scans ranging from 5 to $75^{\circ}$ in varying steps of $0.02^{\circ}$ were used in these experiments.

All vibrational measurements were carried out at room temperature. FT-Raman spectra of topiramate were obtained with a Bruker RFS 100/S, using the $1064 \mathrm{~nm}$ line of a Nd:YAG laser as exciting source, with a power output of $150 \mathrm{~mW}$. The spectral resolution was set to $4 \mathrm{~cm}^{-1}$, and the signal/noise ratio was enhanced by 60 scans in the range of $70 \mathrm{~cm}^{-1}$ to $4000 \mathrm{~cm}^{-1}$. FT-IR spectrum was obtained on a Bruker EQUINOX 55, using a spectral resolution of $4 \mathrm{~cm}^{-1}$. The signal/noise ratio was enhanced by 60 scans from topiramate powder in $\mathrm{KBr}$ pellets in the range of $3500 \mathrm{~cm}^{-1}$ to $400 \mathrm{~cm}^{-1}$. The vibrational frequencies of the topiramate molecule were calculated by Density Functional
Theory (DFT) using the Gaussian98 package, ${ }^{8}$ with the B3LYP method and 6-31G(d,p) basis set, after a suitable geometry optimization. Calculated vibrational spectra (infrared and Raman) were plotted by fitting Lorentzian functions to the peaks, with $10 \mathrm{~cm}^{-1}$ FWHM (full width at half maximum). These were graphically (scale factor set to unity) compared to the experimental results and, with the aid of a visualization software, assisted the vibrational assignments.

Crystal samples were analyzed on a SDT Q600, from TA Instruments, performing TGA and DTA simultaneously. The first experimental condition employed was a heating rate of $10{ }^{\circ} \mathrm{C} \mathrm{min}-1$ under $100 \mathrm{~mL} \mathrm{~min}{ }^{-1}$ nitrogen flux, from 22 to $990^{\circ} \mathrm{C}$. In order to understand the DTA curve around $180^{\circ} \mathrm{C}$ in detail, a second condition was employed, with a heating rate of $2{ }^{\circ} \mathrm{C} \mathrm{min}^{-1}$, also under $100 \mathrm{~mL} \mathrm{~min}^{-1}$ nitrogen flux, from 19 to $350^{\circ} \mathrm{C}$. In both cases, samples were maintained in a platinum pan.

\section{Results and Discussion}

The X-ray powder diffraction pattern obtained from our samples is shown in Figure 2. Sample grinding may have led to some crystals becoming amorphous, which would explain the baseline deviation around $25^{\circ}$. In order to determine whether the sample had the same structure as previously reported in the literature, we calculated all the allowed diffraction angles in the range of 5 to $75^{\circ}$ and matched to the observed peaks. Excellent agreement was obtained. The most intense peaks, together with their diffraction planes, are listed in Table 1.

Figure 3 presents the Raman spectrum of the powder sample of topiramate crystal in the range $70-3500 \mathrm{~cm}^{-1}$ and

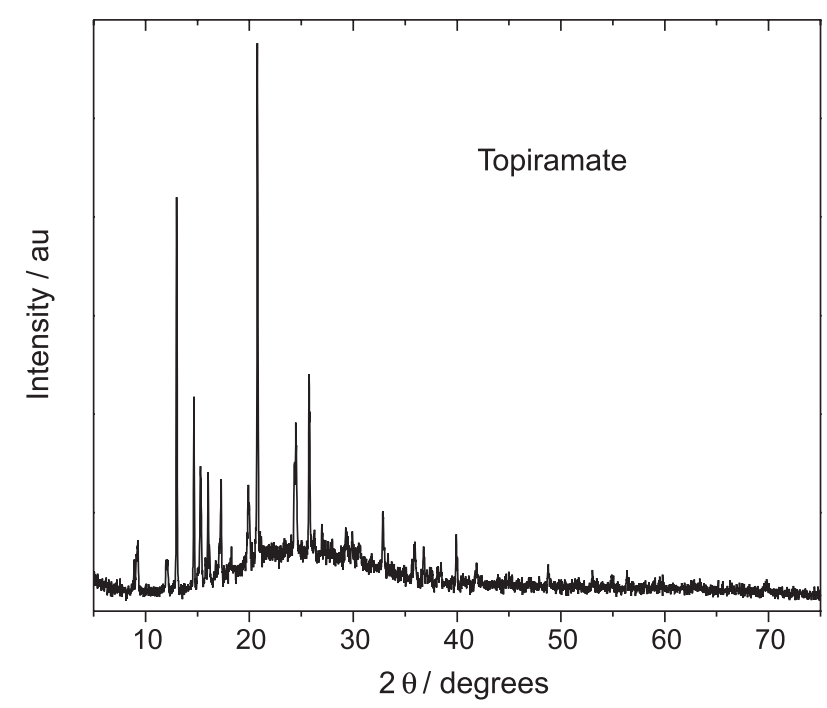

Figure 2. X-ray powder diffraction pattern of topiramate (ground crystals). 
Table 1. Predicted diffraction angles for crystalline topiramate, with the corresponding observed angles and planes of reflection

\begin{tabular}{|c|c|c|}
\hline Calc. & Expt. & h k 1 \\
\hline 9.22 & 9.26 & 011 \\
\hline 12.08 & 12.10 & 012 \\
\hline 13.02 & 13.00 & 101 \\
\hline 14.63 & 14.66 & 110 \\
\hline 15.32 & 15.28 & 111 \\
\hline 16.11 & 16.02 & 020 \\
\hline 17.21 & 17.28 & 112 \\
\hline 19.98 & 19.90 & 113 \\
\hline 20.77 & 20.76 & 121 \\
\hline 24.45 & 24.48 & 123 \\
\hline 25.81 & 25.74 & 105 \\
\hline 32.88 & 32.86 & 041 \\
\hline 35.95 & 35.94 & 027 \\
\hline 36.82 & 36.78 & 036 \\
\hline 40.03 & 39.92 & 045 \\
\hline
\end{tabular}

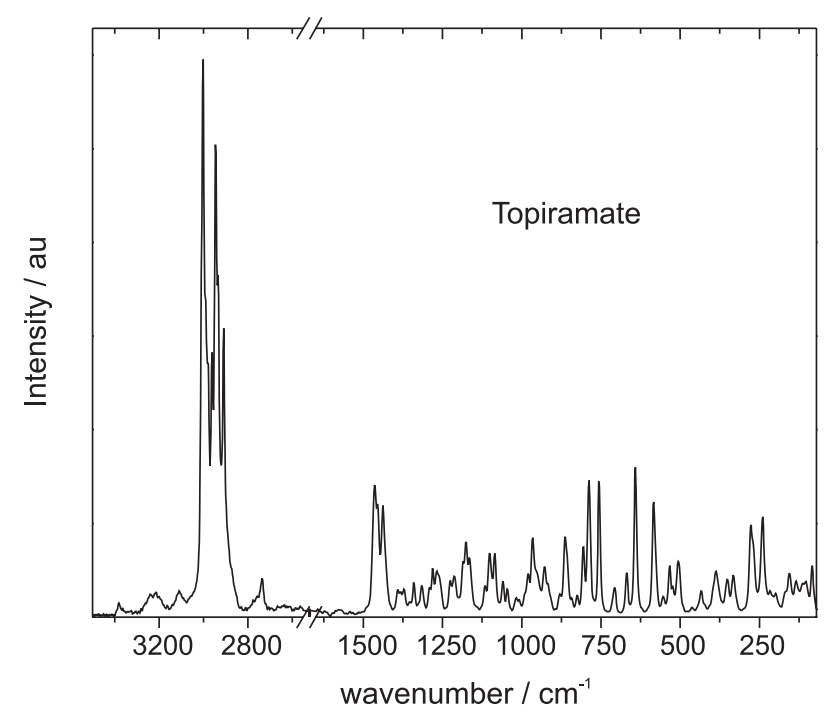

Figure 3. FT-Raman spectrum of topiramate powder, showing the range from 70-3500 $\mathrm{cm}^{-1}$, with a break between 1650 and $2550 \mathrm{~cm}^{-1}$.

Figure 4 presents the FT-IR spectrum of topiramate powder in $\mathrm{KBr}$ for the spectral region $400-3500 \mathrm{~cm}^{-1}$. Both spectra are shown with an axis break from 1650 to $2550 \mathrm{~cm}^{-1}$ due to absence of peaks and to improve clarity. Modes with wavenumber lower than $150 \mathrm{~cm}^{-1}$ are generally assigned as lattice modes. ${ }^{9}$ The tentative assignments of bands observed in the Raman and in the IR spectra of topiramate, based on published vibrational studies on other sulfamates ${ }^{10-17}$ and studies on other correlated materials, ${ }^{18-23}$ as well as DFT calculations, are given in Table 2. In each case, the most intense band was given a value of 100 , and relative intensities are shown in parentheses.

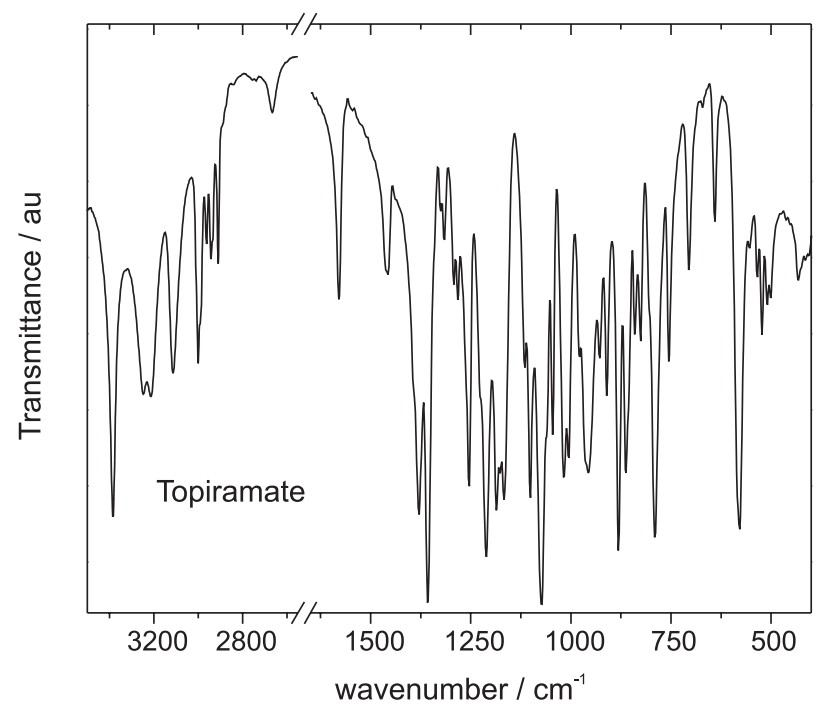

Figure 4. FT-IR spectrum of topiramate powder (KBr pellet) showing the range from $400-3500 \mathrm{~cm}^{-1}$, with a break between 1650 and $2550 \mathrm{~cm}^{-1}$.

According to DFT calculations, the first peaks in this region are associated with C-C torsional motion from methyl groups, at 240, 269, and $278 \mathrm{~cm}^{-1}$, with a considerable contribution of N-S torsion in the first one. However, the $\mathrm{N}-\mathrm{S}$ torsion is tentatively attributed to the band at $332 \mathrm{~cm}^{-1}$, closer to $300 \mathrm{~cm}^{-1}$ as assigned to other sulfamates, ${ }^{14,15,17}$ and accounting for hydrogen bonding effects. The bands at 352 and $386 \mathrm{~cm}^{-1}$ are assigned, respectively, to the $\mathrm{SO}_{3}$ group symmetric and asymmetric rocking modes, also as in other sulfamates. The angular deformations for this same group are seen at 506 and $554 \mathrm{~cm}^{-1}$ (symmetric), and $585 \mathrm{~cm}^{-1}$ (asymmetric). Angular deformations are also found at 641, 669 and $708 \mathrm{~cm}^{-1}$, involving O-C-O, C-O-C and $\mathrm{C}-\mathrm{C}-\mathrm{O}$ bending. Ring breathing modes are observed, according to DFT, at $756 \mathrm{~cm}^{-1}$ (6-membered-ring) and $788 \mathrm{~cm}^{-1}$ (5-membered-ring).

In the optimized geometry, the N-S bond length $(1.668 \AA)$ is close to the one in potassium sulfamate $(1.666 \AA),{ }^{12}$ but the stretching frequency was calculated at the higher value of $859 \mathrm{~cm}^{-1}$ (unscaled). In the crystal the bond length is $1.576 \AA$, so this mode was assigned to the band at $806 \mathrm{~cm}^{-1}$. The group of bands $825,842,864$ and $881 \mathrm{~cm}^{-1}$ are associated with ring deformations due to coupled skeletal stretching and bending modes. Methylene groups rocking modes are assigned separately, the exocyclic one at $928 \mathrm{~cm}^{-1}$ and the endocyclic at a slightly higher frequency of $952 \mathrm{~cm}^{-1}$, due to steric effects from the ring. Rocking from $\mathrm{CH}_{3}$ groups is observed at 966 and $980 \mathrm{~cm}^{-1}$.

The weak band in the Raman spectrum at $1018 \mathrm{~cm}^{-1}$, with the same frequency but stronger in the infrared, is assigned to stretching of the $\mathrm{C}-\mathrm{O}$ bond that holds the sulfamate group and agrees very well with the calculated value of $1022 \mathrm{~cm}^{-1}$ (unscaled). 
Table 2. Wavenumber $\left(\mathrm{cm}^{-1}\right)$ and tentative assignment of the bands observed in the FT-Raman and FT-IR spectra of crystalline topiramate at room temperature

\begin{tabular}{|c|c|c|c|c|c|}
\hline $\begin{array}{l}\text { Wavenumber/ }\left(\mathrm{cm}^{-1}\right) \\
\text { FT-Raman }\end{array}$ & $\begin{array}{c}\text { Wavenumber/ }\left(\mathrm{cm}^{-1}\right) \\
\text { FT-IR }\end{array}$ & Assignment & $\begin{array}{c}\text { Wavenumber/ }\left(\mathrm{cm}^{-1}\right) \\
\text { FT-Raman }\end{array}$ & $\begin{array}{c}\text { Wavenumber/ }\left(\mathrm{cm}^{-1}\right) \\
\text { FT-IR }\end{array}$ & Assignment \\
\hline 84 (009) & - & lattice modes & 1045 (004) & 1045 (049) & $v_{\mathrm{s}} \mathrm{SO}_{3}$ \\
\hline $102(004)$ & - & lattice modes & $1059(005)$ & 1059 (023) & v C-O (rings) \\
\hline $114(004)$ & - & lattice modes & - & $1074(100)$ & v C-O (rings) \\
\hline $134(005)$ & - & lattice modes & 1085 (010) & - & v C-O (rings) \\
\hline $155(007)$ & - & lattice modes & 1097 (003) & - & v C-O (rings) \\
\hline $169(002)$ & - & lattice modes & 1102 (009) & $1102(060)$ & v C-O (rings) \\
\hline $198(003)$ & - & - & $1116(004)$ & $1116(034)$ & tw $\mathrm{NH}_{2}$ \\
\hline $215(002)$ & - & - & 1164 (007) & $1165(055)$ & $v_{\mathrm{s}} \mathrm{SO}_{3}$ \\
\hline $240(018)$ & - & $\tau \mathrm{C}-\mathrm{C}$ & $1176(011)$ & $1175(034)$ & $v \mathrm{CCC}, \mathrm{CCO}$ \\
\hline $269(010)$ & - & $\tau \mathrm{C}-\mathrm{C}$ & $1186(006)$ & $1185(055)$ & $v_{\mathrm{s}} \mathrm{SO}_{3}$ \\
\hline $278(014)$ & - & $\tau \mathrm{C}-\mathrm{C}$ & $1213(005)$ & $1211(084)$ & tw $\mathrm{CH}_{2},(+\delta \mathrm{CH})$ \\
\hline $332(007)$ & - & $\tau \mathrm{N}-\mathrm{S}$ & $1226(004)$ & $1228(026)$ & tw $\mathrm{CH}_{2},(+\delta \mathrm{CH})$ \\
\hline $352(005)$ & - & $\rho_{\mathrm{s}} \mathrm{SO}_{3}$ & $1259(005)$ & 1254 (057) & $\mathrm{v}_{\mathrm{as}} \mathrm{SO}_{3}$ \\
\hline $386(007)$ & - & $\rho_{\text {as }} \mathrm{SO}_{3}$ & 1268 (006) & 1263 (035) & tw $\mathrm{CH}_{2},(+\delta \mathrm{CH})$ \\
\hline $394(002)$ & - & - & $1281(007)$ & $1282(024)$ & tw $\mathrm{CH}_{2},(+\delta \mathrm{CH})$ \\
\hline 434 (004) & $431(010)$ & $\delta \mathrm{CCC}$ & $1291(003)$ & 1293 (022) & tw $\mathrm{CH}_{2},(+\delta \mathrm{CH})$ \\
\hline $463(001)$ & - & - & 1315 (004) & $1316(017)$ & $\delta \mathrm{C}-\mathrm{H}$ in phase \\
\hline- & $501(019)$ & - & - & 1325 (007) & - \\
\hline $506(010)$ & $510(018)$ & $\delta_{\mathrm{s}} \mathrm{SO}_{3}$ & $1340(005)$ & - & $\delta \mathrm{C}-\mathrm{H}$ out of phase \\
\hline $523(002)$ & $523(030)$ & - & $1354(001)$ & $1357(092)$ & $\omega \mathrm{CH}_{2}$ \\
\hline $533(008)$ & $535(017)$ & $\delta \mathrm{C}-\mathrm{C}-\mathrm{O}$ & $1371(003)$ & $1379(052)$ & $\delta_{\mathrm{s}} \mathrm{CH}_{3}$ (dimethyl) \\
\hline $554(002)$ & $554(012)$ & $\delta_{\mathrm{s}} \mathrm{SO}_{3}$ & $1382(003)$ & - & - \\
\hline $580(011)$ & $577(074)$ & - & $1391(003)$ & $1393(036)$ & $\delta_{\mathrm{s}} \mathrm{CH}_{3}$ (dimethyl) \\
\hline $585(017)$ & $586(050)$ & $\delta_{\text {as }} \mathrm{SO}_{3}$ & $1431(005)$ & - & $\delta_{\text {as }} \mathrm{CH}_{3}$ \\
\hline $641(030)$ & $641(029)$ & $\delta$ O-C-O (5-ring) & $1438(017)$ & - & $\delta_{\text {as }} \mathrm{CH}_{3}$ \\
\hline $669(008)$ & $673(004)$ & $\delta$ C-O-C (5-ring) & $1455(015)$ & $1458(029)$ & $\delta_{\mathrm{s}} \mathrm{CH}_{2}(\mathrm{exo})$ \\
\hline $708(005)$ & $705(047)$ & $\delta$ C-C-O & $1465(021)$ & - & $\delta_{\mathrm{s}} \mathrm{CH}_{2}$ (endo) \\
\hline $756(027)$ & $754(044)$ & breathing (6-ring) & $1581(001)$ & $1579(044)$ & $\delta_{\mathrm{s}} \mathrm{NH}_{2}$ \\
\hline $788(026)$ & $790(089)$ & breathing (5-ring) & - & $2666(010)$ & overtone \\
\hline $806(011)$ & $805(009)$ & $v \mathrm{~N}-\mathrm{S}$ & $2739(006)$ & $2736(006)$ & overtone \\
\hline $825(001)$ & $826(036)$ & ring modes & $2888(008)$ & $2844(001)$ & overtone \\
\hline $842(001)$ & $839(031)$ & ring modes & $2909(045)$ & $2910(032)$ & $v \mathrm{C}-\mathrm{H}$ \\
\hline $856(007)$ & $855(036)$ & ring modes & $2933(043)$ & 2934 (017) & $v_{\mathrm{s}} \mathrm{CH}_{3}$ in phase \\
\hline $864(013)$ & $863(054)$ & ring modes & 2945 (075) & $2943(023)$ & $v_{\mathrm{s}} \mathrm{CH}_{3}$ in phase \\
\hline $881(002)$ & $881(085)$ & ring modes & $2962(032)$ & 2962 (019) & $v_{\mathrm{s}} \mathrm{CH}_{2}(\mathrm{exo})$ \\
\hline $910(001)$ & $910(044)$ & - & 2979 (028) & - & $\mathrm{v}_{\mathrm{as}} \mathrm{CH}_{2}$ (endo) \\
\hline 917 (003) & - & - & 2989 (028) & 2987 (025) & $v_{\text {as }} \mathrm{CH}_{3}$ out of phase \\
\hline 928 (007) & $928(028)$ & $\rho \mathrm{CH}_{2}(\mathrm{exo})$ & $3003(100)$ & $3001(043)$ & $v_{\text {as }} \mathrm{CH}_{3}$ in phase \\
\hline $952(006)$ & $951(056)$ & $\rho \mathrm{CH}_{2}$ (endo) & $3110(003)$ & $3115(036)$ & $2 \times \delta_{s} \mathrm{NH}_{2}$ \\
\hline $966(012)$ & $965(041)$ & $\rho \mathrm{CH}_{3}$ & $3210(003)$ & $3206(030)$ & $v_{\mathrm{s}} \mathrm{NH}_{2}$ \\
\hline $980(005)$ & $979(023)$ & $\rho \mathrm{CH}_{3}$ & $3243(003)$ & $3251(039)$ & $v_{\mathrm{s}} \mathrm{NH}_{2}$ \\
\hline $1008(001)$ & $1005(053)$ & - & $3380(002)$ & $3385(065)$ & $\mathrm{v}_{\mathrm{as}} \mathrm{NH}_{2}$ \\
\hline $1018(002)$ & $1018(062)$ & $v \mathrm{C}-\mathrm{O}(\mathrm{exo})$ & - & - & - \\
\hline
\end{tabular}

$\rho=$ rocking; $\tau=$ torsion; $\omega=$ wagging; $\delta=$ bending; $\nu=$ stretching; as = asymmetric; $s=$ symmetric; $\mathrm{tw}=$ twisting. 
As observed from other sulfamates, the $\mathrm{SO}_{3}$ group gives rise to three symmetric and one asymmetric stretching vibrations. This is due to a lifting of degeneracy by the crystal symmetry. One of each kind was observed in the calculations, the symmetric at $1164 \mathrm{~cm}^{-1}$ and the other at $1390 \mathrm{~cm}^{-1}$, coupled to other vibrations. The former was assigned to the band at $1164 \mathrm{~cm}^{-1}$, together with 1045 and $1186 \mathrm{~cm}^{-1}$, and the latter at $1259 \mathrm{~cm}^{-1}$, in better agreement with the literature. The calculated frequency of $1183 \mathrm{~cm}^{-1}$ is attributed to CCC and CCO stretching, and tentatively assigned to the peak at $1176 \mathrm{~cm}^{-1}$.

The group of bands from 1059 to $1102 \mathrm{~cm}^{-1}$ are associated with $\mathrm{C}-\mathrm{O}$ stretching from the rings, in agreement with DFT calculations, except for the peak at $1102 \mathrm{~cm}^{-1}$ which is shown as a twist from the $\mathrm{NH}_{2}$ group. This mode is assigned to the band at $1116 \mathrm{~cm}^{-1}$ in order to account for hydrogen bonding effects, and to be closer to the literature values.

The next group, from 1213 to $1291 \mathrm{~cm}^{-1}$, except for the band at $1259 \mathrm{~cm}^{-1}$, comprises bands assigned to $\mathrm{CH}_{2}$ twisting vibrations, usually coupled to bending of $\mathrm{CH}$, with the modes involving the exocyclic methylene group lying higher in energy than the ones associated to the endocyclic $\mathrm{CH}_{2}$.

Bending vibrations from $\mathrm{CH}$ groups are assigned to the bands in 1315 (in phase) and $1340 \mathrm{~cm}^{-1}$ (out of phase, Raman only). The very weak peak at $1354 \mathrm{~cm}^{-1}$ in the Raman spectrum, but very intense in the infrared, is assigned to the $\mathrm{CH}_{2}$ wagging vibration. Methyl groups symmetric deformations (umbrella) are assigned to the bands at 1371 and $1391 \mathrm{~cm}^{-1}$.

Asymmetric bending from $\mathrm{CH}_{3}$ groups are assigned to bands at 1431 and $1438 \mathrm{~cm}^{-1}$, followed by symmetric bending (scissoring) from methylene groups, the exocyclic at $1455 \mathrm{~cm}^{-1}$ and the endocyclic at $1465 \mathrm{~cm}^{-1}$, as in fructopyranose. ${ }^{22}$ Last in the low frequency region is the $\mathrm{NH}_{2}$ scissoring mode at $1581 \mathrm{~cm}^{-1}$, one of the highest values as compared to other sulfamates.

The high-wavenumber range (higher than $2700 \mathrm{~cm}^{-1}$ ) is the region where stretching vibrations of $\mathrm{CH}_{3}, \mathrm{CH}_{2}$ and $\mathrm{NH}_{2}$ groups are expected to be observed. As occurs with other materials presenting $\mathrm{CH}_{2}$ and $\mathrm{CH}_{3}$ units, this region is the spectral range where the most intense peaks in the Raman spectra are observed. ${ }^{9}$ The stretching vibrations of $\mathrm{NH}_{2}$ are found with the highest energies: the asymmetric stretching is the peak at 3380 and $3385 \mathrm{~cm}^{-1}$, respectively, in the Raman and in the IR spectra. The symmetric stretching, on its turn, is observed as a doublet at 3243 and $3210 \mathrm{~cm}^{-1}$ in the Raman spectrum, and at 3251 and $3206 \mathrm{~cm}^{-1}$ in the infrared. This is attributed to the fact that, within the crystal, topiramate molecules are held together in linear chains by asymmetric hydrogen bondings (only one of the hydrogens in the amine group participates), running in opposite directions. The peak observed at $c a .3110 \mathrm{~cm}^{-1}$ can be attributed to an overtone due to Fermi resonance from the amine group scissoring mode, as occurs for other sulphamates. ${ }^{10,11,14}$ The asymmetric stretchings of $\mathrm{CH}_{3}$ are observed at 3003 (in phase) and $2989 \mathrm{~cm}^{-1}$ (out of phase), followed by the asymmetric stretching of endocyclic $\mathrm{CH}_{2}$ group at $2979 \mathrm{~cm}^{-1}$. The band observed at $2962 \mathrm{~cm}^{-1}$ is assigned to the symmetric stretching of exocyclic $\mathrm{CH}_{2}$; this value is almost $30 \mathrm{~cm}^{-1}$ higher than that observed for fructopyranose. ${ }^{20}$ This is attributed to the presence of the sulfamate group, and supported by the DFT calculations. Additionally, DFT calculations indicate that the peaks at 2933 and $2945 \mathrm{~cm}^{-1}$ are associated to symmetric stretching of $\mathrm{CH}_{3}$, while stretching of $\mathrm{CH}$ is observed at $2909 \mathrm{~cm}^{-1}$.

The band at $2736 \mathrm{~cm}^{-1}$ could be seen as originated from an aldehyde group formed after a partial ring-opening, possibly caused by water in the sample. However, this band is also observed in Raman experiments performed on single crystals (not shown), where the effect of water is negligible, so a possible source for this mode is the overtone of the band at $1371 \mathrm{~cm}^{-1}$. Following the same reasoning, the bands 2666 (infrared only) and $2888 \mathrm{~cm}^{-1}$ were also tentatively assigned as overtones.

We also performed a thermal analysis study in order to obtain information about both (i) possible polymorphic modification of the material and (ii) the decomposition process occurring at high temperatures. It is well known that to screen for polymorphs of a certain crystal we would have to perform crystallization experiments from a diverse range of solvents. Also, for a specific solvent it is possible to obtain crystals with different symmetries depending on parameters such as $\mathrm{pH}$ and temperature. ${ }^{23}$ However, for each polymorph, the temperatures of the phase transformations are well established and, as a consequence, the thermal analysis is an important tool to search for polymorphism. The discovery of new polymorphs is important because an understanding of the diverse solid state forms can lead to better design and control of drug performance. With these objectives we performed TGA and DTA measurements. In a first run of TGA, a mass loss of $46.8 \%$ was observed around $180{ }^{\circ} \mathrm{C}$, followed by a further mass loss of $20.8 \%$ in the interval $180-270{ }^{\circ} \mathrm{C}$. Then, mass continues to reduce slowly until the temperature reaches $990^{\circ} \mathrm{C}$, when only $17.8 \%$ of the total mass is present. DTA exhibited an endothermic peak at $127.1{ }^{\circ} \mathrm{C}$ due to melting of the sample, and another endothermic peak at $177.1^{\circ} \mathrm{C}$, immediately followed by a highly exothermic "loop" at $183.4{ }^{\circ} \mathrm{C}$. This loop is due to a heat release greater than the heating rate of the instrument, which makes it stop heating and then 


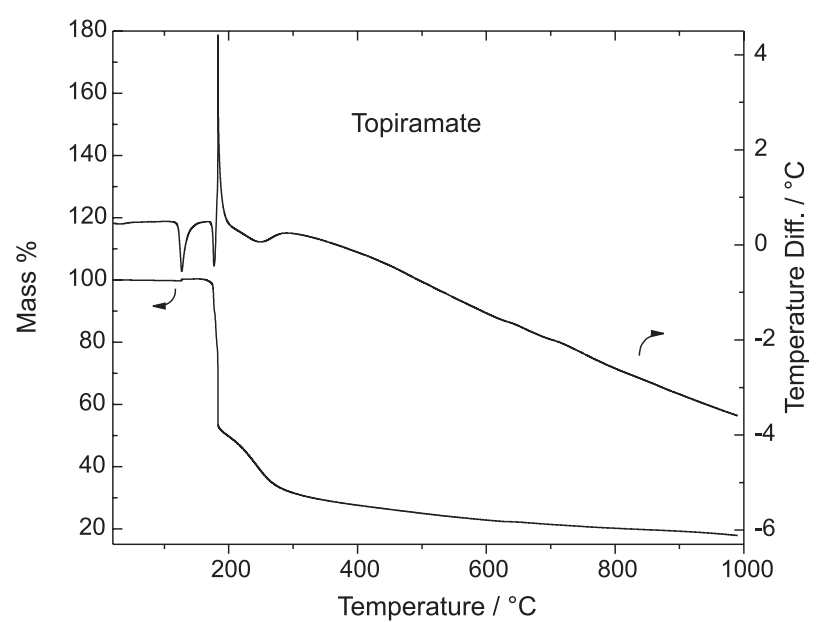

Figure 5. TGA (below, left axis) and DTA (above, right axis) graphs for topiramate, from 22 to $990{ }^{\circ} \mathrm{C}$, at a heating rate of $10{ }^{\circ} \mathrm{C} \mathrm{min}-1$ and $100 \mathrm{~mL} \mathrm{~min}^{-1}$ nitrogen flux.

recovers after the process is finished. These results are shown in Figure 5.

In order to further shed light on the phenomenon in the region around $180^{\circ} \mathrm{C}$, a lower heating rate was employed. TGA results (not shown) were roughly the same (44.4\% mass loss around $180{ }^{\circ} \mathrm{C}$, followed by a $19.7 \%$ mass loss up to $260{ }^{\circ} \mathrm{C}$ ), but DTA recorded melting at $121.4^{\circ} \mathrm{C}$ and two sharp exothermic peaks $\left(179.6\right.$ and $\left.181.3^{\circ} \mathrm{C}\right)$ instead of the loop just following the endothermic peak at $178.5^{\circ} \mathrm{C}$, as shown in Figure 6.

According to the literature, topiramate melts between 125 and $126^{\circ} \mathrm{C} .{ }^{1}$ The deviations observed experimentally are due to the different heating rates used, the higher the rate, higher the melting temperature observed. The endothermic peak at $178{ }^{\circ} \mathrm{C}$ is attributed to the first stage of decomposition, where topiramate loses the sulfamate group, preceding mass loss. In a second stage,

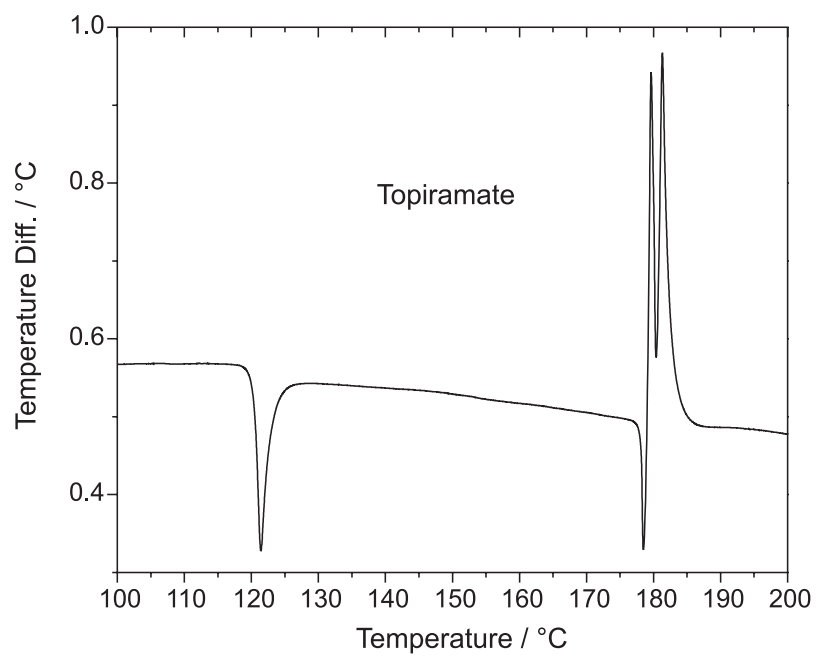

Figure 6. DTA of topiramate from $19{ }^{\circ} \mathrm{C}$ to $350{ }^{\circ} \mathrm{C}$, at a heating rate of $2{ }^{\circ} \mathrm{C} \min ^{-1}$ and $100 \mathrm{~mL} \mathrm{~min}^{-1}$ nitrogen flux. sulfamate decomposes to produce sulfate anions (there is no detectable mass loss here) and the previous molecule (2,3:4,5-bis- $O$-methylethylidene- $\beta$ - $D$-fructopyranose) decomposes to fructose, thus accounting for the $46.8 \%$ mass loss. Thirdly, due to the presence of sulfate ions, we suggest that sulfuric acid is formed and then dehydrates the fructose molecule, accounting for the large volume of the black residue observed at the end of the run. This is proposed in analogy to the dehydration reaction of sugars by sulfuric acid, which is well known to release a large amount of heat and water steam, expanding the charcoal thus formed.

\section{Conclusions}

In this letter we have presented vibrational and thermal properties of topiramate, an anticonvulsant drug. From this study, through FT-Raman, FT-IR investigations and DFT calculations, most of observed bands of crystalline topiramate were tentatively assigned. The second main point addressed was the thermal behavior of the material, an important issue for differentiating crystalline modifications, in particular related to materials used as medicines. The sharpness of DTA peaks from the topiramate crystals investigated in this work was a good indication of sample purity. Topiramate thermal stability was verified and no phase transition other than melting was observed. Also, an insight about the decomposition process was provided in this work.

\section{Acknowledgments}

The authors would like to thank gratefully JanssenCilag Farmacêutica S. A. for providing topiramate and CNPq and CAPES for supporting this research. D. M. Sena Jr. gratefully acknowledges financial support from FUNCAP, and P.T.C.F. acknowledges CENAPAD-SP (project 373) for computational resources.

\section{References}

1. Maryanoff, B. E.; Costanzo, M. J.; Nortey, S. O.; Greco, M. N.; Shank, R. P.; Schupsky, J. J.; Ortegon, M. P.; Vaught, J.L.; J. Med. Chem. 1998, 41, 1315.

2. Maryanoff, B. E.; Nortey, S. O.; Gardocki, J. F.; Shank, R. P.; Dodgson, S. P.; J. Med. Chem. 1987, 30, 880.

3. Maryanoff, B. E.; McComsey, D. F.; Costanzo, M. J.; Hochman, C.; Smith-Swintosky, V.; Shank, R. P.; J. Med. Chem. 2005, 48, 1941.

4. Datta, S.; Grant, D. J. W.; Nature Rev. Drug Disc. 2004, 3, 42; Dunitz, J. D.; Bernstein, J.; Acc. Chem. Res. 1995, 28, 193; Brittain, H. G.; J. Pharm. Sci. 1997, 86, 405. 
5. Kubicki, M.; Codding, P. W.; Litster, S. A.; Szkaradzinska, M. B.; Bassyouni, H. A. R.; J. Mol. Struct. 1999, 474, 255.

6. Micheel, A. P.; Ko, C. Y.; Guh, H. Y.; J. Chromatogr. B 1998 , 709, 166; Klockow-Beck, A.; Nick, A.; Geisshuesler, St.; Schaufelberger, D.; J. Chromatogr. B 1998, 720, 141; Biró, A.; Pergel, É.; Árvai, G.; Ilisz, I.; Szepesi, G.; Péter, A.; Lukács, F.; Chromatographia 2006, 63, S137.

7. Pînzaru, S. C.; Pavel, I.; Leopold, N.; Kiefer, W.; J. Raman Spectrosc. 2004, 35, 338.

8. Frisch, M. J.; Trucks, G. W.; Schlegel, H. B.; Scuseria, G. E.; Robb, M. A.; Cheeseman, J. R.; Zakrewski, V. G.; Montgomery, J. A.; Stratman, R. E.; Vurant, J. C.; Dapprich, S.; Millam, J. M.; Daniels, A. D.; Kudin, K. N.; Strain, M. C.; Farkas, O.; Tomasi, J.; Barone, V.; Cossi, M.; Cammi, R.; Mennuci, B.; Pomelli, C.; Adamo, C.; Clifford, S.; Ochterski, J.; Petersson, G. A.; Ayala, P. Y.; Cui, Q.; Morokuma, K.; Malick, D. K.; Rabuch, A. D.; Raghavachari, K.; Foresman, J. B.; Cioslowshi, J.; Ortiz, J. V.; Stefanov, B. B.; Liu, G.; Liashenko, A.; Piskorz, P.; Komaromi, I.; Gomperts, R.; Martin, R. L.; Foz, D. J.; AlLaham, T. M.; Peng, C. Y.; Nanayakkara, A.; Gonzalez, C.; Challacombe, M.; Gill, P. M. W.; Jonson, B.; Chen, W.; Wong, M. W.; Andres, J. L.; Gonzalez, C.; Head-Gordon, M.; Reploge, E. S.; Pople, J. A.; Gaussian 98, Revision A.11.2; Gaussian, Inc., Pittsburgh PA, 2001.

9. Lima Jr., J. A.; Freire, P. T. C.; Lima, R. J. C.; Moreno, A. J. D.; Mendes J.; Melo, F. E. A.; J. Raman Spectrosc. 2005, 36, 1076.

10. Vuagnat, A. M.; Wagner, E. L.; J. Chem. Phys. 1957, 26, 77.

11. Sundara Raj, A.; Muthusubramanian, P.; Krishnamurthy, N.; J. Raman Spectrosc. 1981, 11, 127.
12. Sundara Raj, A.; Muthusubramanian, P.; J. Mol. Struct. 1982, 89, 291.

13. Muthusubramanian, P.; Sundara Raj, A.; J. Raman Spectrosc. 1982, 12, 24.

14. Muthusubramanian, P.; Sundara Raj, A.; J. Raman Spectrosc. 1983, 14, 221.

15. Muthusubramanian, P.; Santos, P. S.; Sala, O.; J. Mol. Struct. 1984, 112, 233.

16. Ilczyszyn, M. M.; Wierzejewska M.; Ciunik, Z.; Phys. Chem. Chem. Phys. 2000, 2, 3503.

17. Ilczyszyn, M. M.; Ilczyszyn, M.; J. Raman Spectrosc. 2003, 34, 693.

18. Moreno, A. J. D.; Freire, P. T. C.; Guedes, I.; Melo, F. E. A.; Mendes J.; Sanjurjo, J. A.; Braz. J. Phys. 1999, 29, 380.

19. Barrett, T. W.; Spectrochim. Acta 1981, 37A, 233.

20. Baran, J.; Ratajczak, H.; Lutz, E. T. G.; Verhaegh, N.; Luinge, H. J.; van der Maas, J. H.; J. Mol. Struct. 1994, 326, 109.

21. Söderholm, S.; Roos, Y. H.; Meinander, N.; Hotokka, M.; J. Raman Spectrosc. 1999, 30, 1009.

22. Benbrahim, N.; Sekkal-Rahal, M.; Vergoten, G.; Spectrochim. Acta 2002, 58A, 3021.

23. Almeida, F. M.; Freire, P. T. C.; Lima, R. J. C.; Remédios, C. M. R.; Mendes, J.; Melo, F. E. A.; J. Raman Spectrosc. 2006, 37, 1296.

Received: October 10, 2007 Web Release Date: October 10, 2008

FAPESP helped in meeting the publication costs of this article. 